\title{
Identification of a Mycobacterium tuberculosis Cyclic Dinucleotide Phosphodiesterase Inhibitor
}

\author{
Caroline W. Karanja ${ }^{a}$ Kofi S. Yeboah ${ }^{a}$ and Herman O. Sintim ${ }^{a, b, c *}$
}

a Department of Chemistry, Purdue university, 560 Oval Drive, West Lafayette, Indiana 47907-2084

${ }^{\mathrm{b}}$ Institute for Drug Discovery, Purdue University, 720 Clinic Drive, West Lafayette, IN 47907, USA.

${ }^{\mathrm{C}}$ Purdue Institute of Inflammation, Immunology, and Infectious Disease, West Lafayette, IN, 47907, USA.

${ }^{*}$ Corresponding author. Email: hsintim@purdue.edu
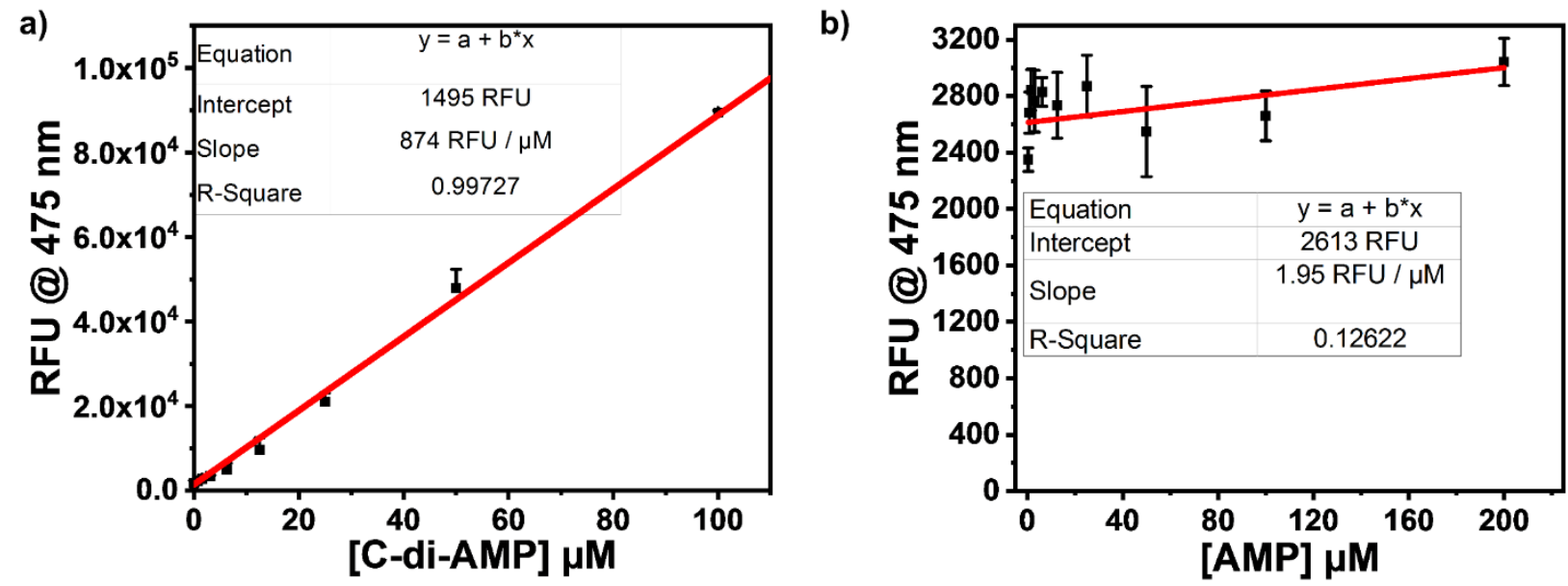

Figure S1: Effects of c-di-AMP and AMP on coralyne fluorescence emission. a) Calibration for coralyne fluorescence as function of c-di-AMP concentration. b) Calibration for coralyne fluorescence as function of AMP concentration 
a)

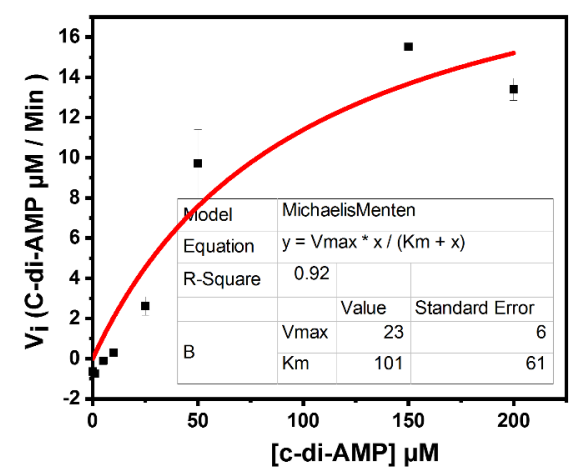

b)

\begin{tabular}{|l|l|l|}
\hline [C-di-AMP] & [KI] & Z-Factor \\
\hline $50 \mu \mathrm{M}$ ( Kinetics) & $3 \mathrm{mM}$ & 0.33 \\
\hline $50 \mu \mathrm{M}$ (Kinetics) & $10 \mathrm{mM}$ & 0.41 \\
\hline $70 \mu \mathrm{M}$ (Kinetics) & $10 \mathrm{mM}$ & 0.61 \\
\hline $70 \mu \mathrm{M}$ (Endpoint) & $10 \mathrm{mM}$ & 0.71 \\
\hline
\end{tabular}

Figure S2: Optimization of coralyne assay for high throughput screening of MTB CdnP inhibitors. a) Michaelis-Menten curve for MTB CdnP determined using coralyne assay. b) Z-factor for different experimental parameters determined with $0.5 \mu \mathrm{M}$ MTB CdnP.
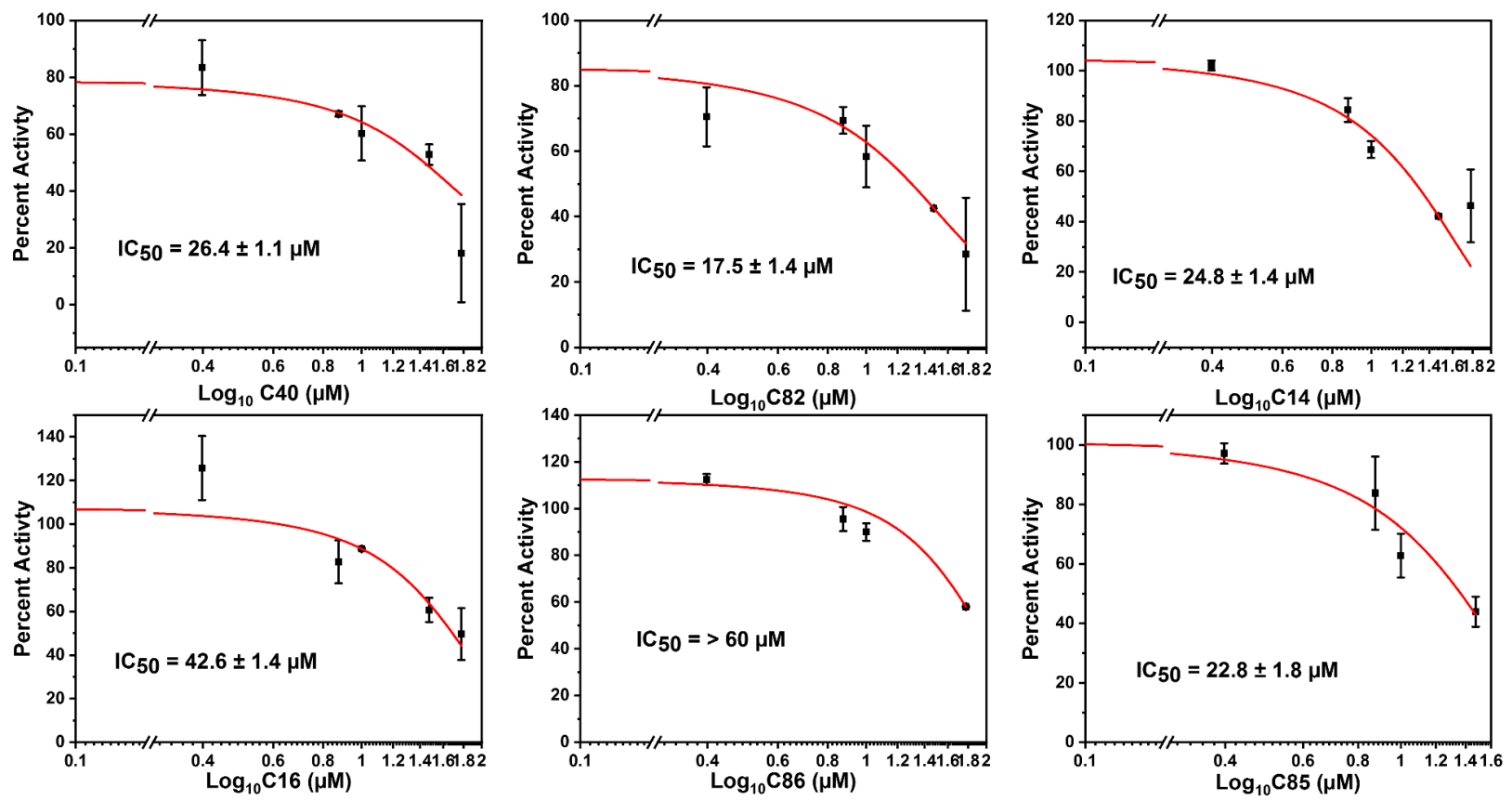

Figure S3. Concentration dependent Mtb CdnP inhibition by compounds, quantified with the coralyne assay. Curves were generated with origin in-built dose response function (see equation 1 in the material and methods section). Reaction conducted at $30^{\circ} \mathrm{C}$ with $50 \mathrm{nM}$ MTB CdnP, $100 \mu \mathrm{M}$ c-di-AMP, $10 \mathrm{mM} \mathrm{KI}, 10 \mu \mathrm{M}$ coralyne in $1 \mathrm{x}$ reaction buffer $\left(50 \mathrm{mM}\right.$ Tris- $\mathrm{HCl} \mathrm{pH}$ 8.0, $5 \mathrm{mM} \mathrm{MnCl}_{2}$ ) supplemented with $0.0025 \%$ Triton X-100. Experiment done in triplicates. 


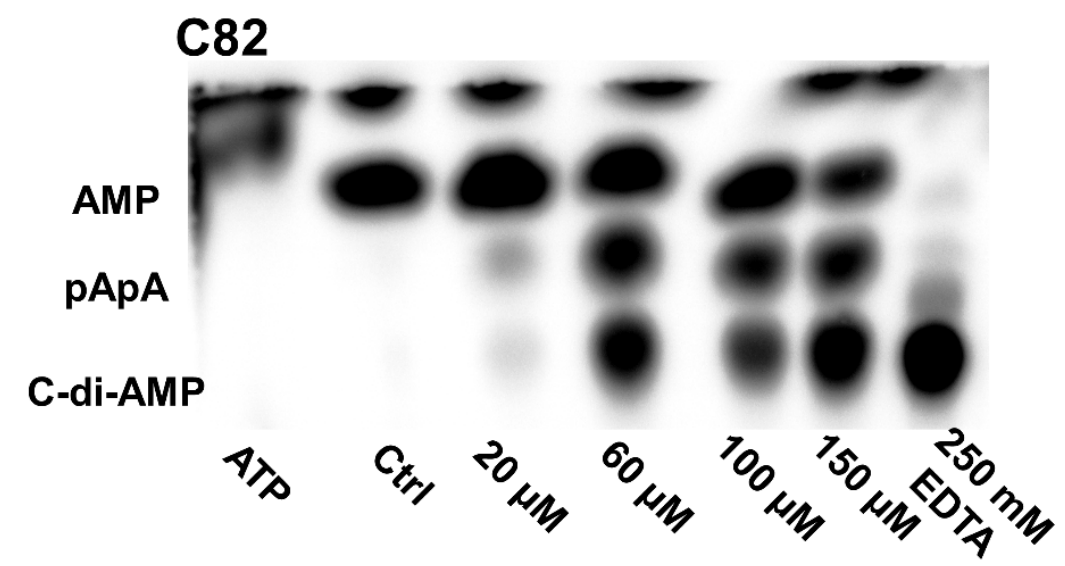

Figure S4: Visualization of c-di-AMP cleavage by $0.75 \mu \mathrm{M}$ Mtb CndP in the absence and presence of varying concentrations of C82. Experiment conducted with $0.75 \mu \mathrm{M} \mathrm{CdnP}, 70 \mu \mathrm{M}$ c-di-AMP, $6.6 \mathrm{nM}{ }^{32} \mathrm{P}$-cdi-AMP in $1 \mathrm{x}$ reaction buffer $\left(50 \mathrm{mM}\right.$ Tris- $\left.\mathrm{HCl} \mathrm{pH} \mathrm{8.0,5} \mathrm{mM} \mathrm{MnCl}_{2}\right)$ and incubated for $1 \mathrm{~h}$ at $37^{\circ} \mathrm{C}$.
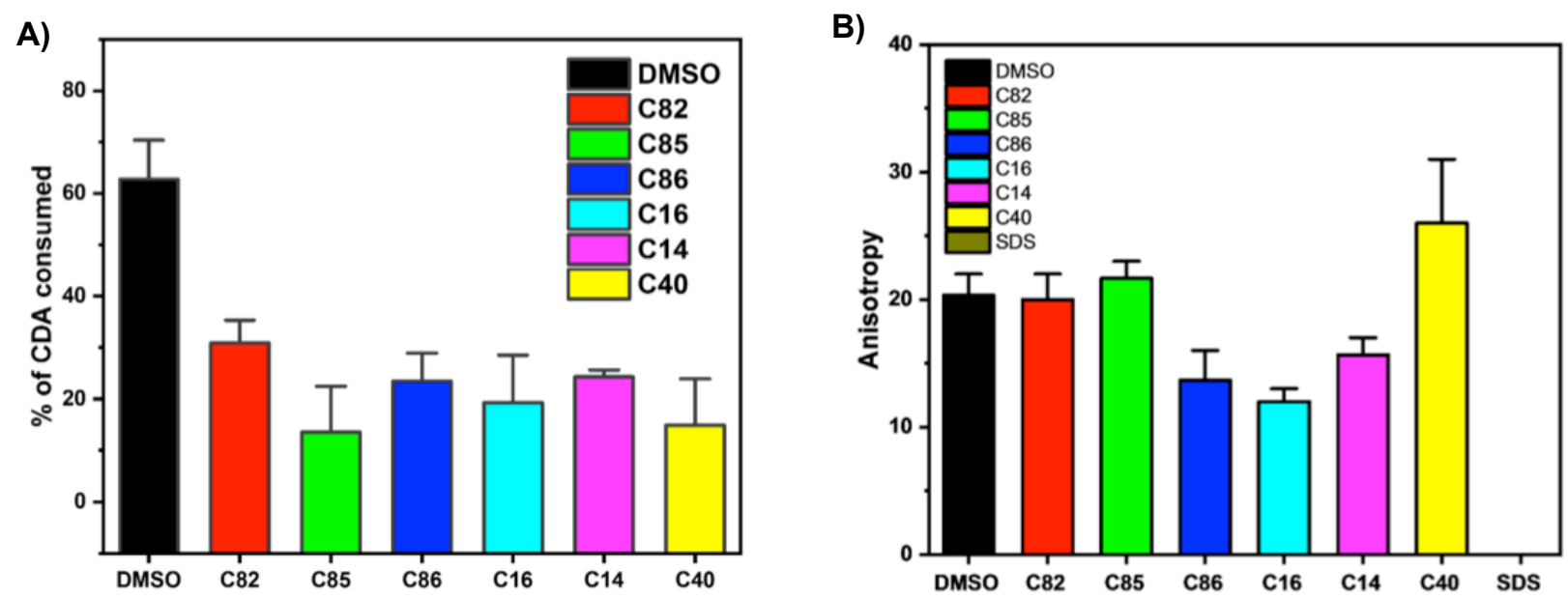

Figure S5: A) MTB CdnP reactions were set up in the presence and absence of compounds (50 $\mu \mathrm{M})$ using $15 \mu \mathrm{M}$ c-di-AMP, $5 \mathrm{mM} \mathrm{MnCl}$, $50 \mathrm{nM}$ MTB CdnP in $1 \mathrm{x}$ buffer $(50 \mathrm{mM}$ Tris- $\mathrm{HCl}, \mathrm{pH}=8.0)$. The reactions were incubated for 5 minutes at $35^{\circ} \mathrm{C}$, followed by another incubation at $95^{\circ} \mathrm{C}$ for 5 minutes to quench the reaction. The leftover c-di-AMP was detected using the recently described hSTING fluorescence polarization assay. ${ }^{1}$ The amount of c-di-AMP consumed was determined by subtracting the c-di-AMP leftover from the initial amount of c-di-AMP used in the reaction. Percent of c-di-AMP consumed was computed by dividing the amount of c-di-AMP consumed by the initial amount of c-di-AMP used.

B) $50 \mathrm{nM}$ of MTB CdnP was incubated with $50 \mu \mathrm{M}$ of compounds in $1 \mathrm{x}$ buffer $(50 \mathrm{mM}$ Tris- $\mathrm{HCl}, \mathrm{pH}=8.0)$ for 1 hour at room temperature. For controls, $50 \mathrm{nM}$ of MTB CdnP was incubated with DMSO or $5 \%$ Sodium Dodecyl Sulfate (SDS) in $1 \mathrm{x}$ buffer $(50 \mathrm{mM}$ Tris- $\mathrm{HCl}, \mathrm{pH}=8.0)$ for 1 hour at room temperature. After incubation the mixtures were dialyzed in $1 \mathrm{x}$ reaction buffer $(50 \mathrm{mM}$ Tris- $\mathrm{HCl}, \mathrm{pH}=8.0)$ using PlusOne Mini Dialysis Kit (GE Healthcare) per manufacturer's instructions. After dialysis, reactions were set up by adding $30 \mu \mathrm{M} \mathrm{c}$-di-AMP and $5 \mathrm{mM} \mathrm{MnCl} \mathrm{m}_{2}$ to the dialyzed mix, followed by 30 minutes incubation at $35^{\circ} \mathrm{C}$. The reactions were then quenched by heat denaturation at $95^{\circ} \mathrm{C}$ for 5 minutes. The hSTING fluorescence polarization assay was used to detect activity of MTB CdnP. For this assay, anisotropy value is proportional to PDE enzymatic activity. ${ }^{1}$ 


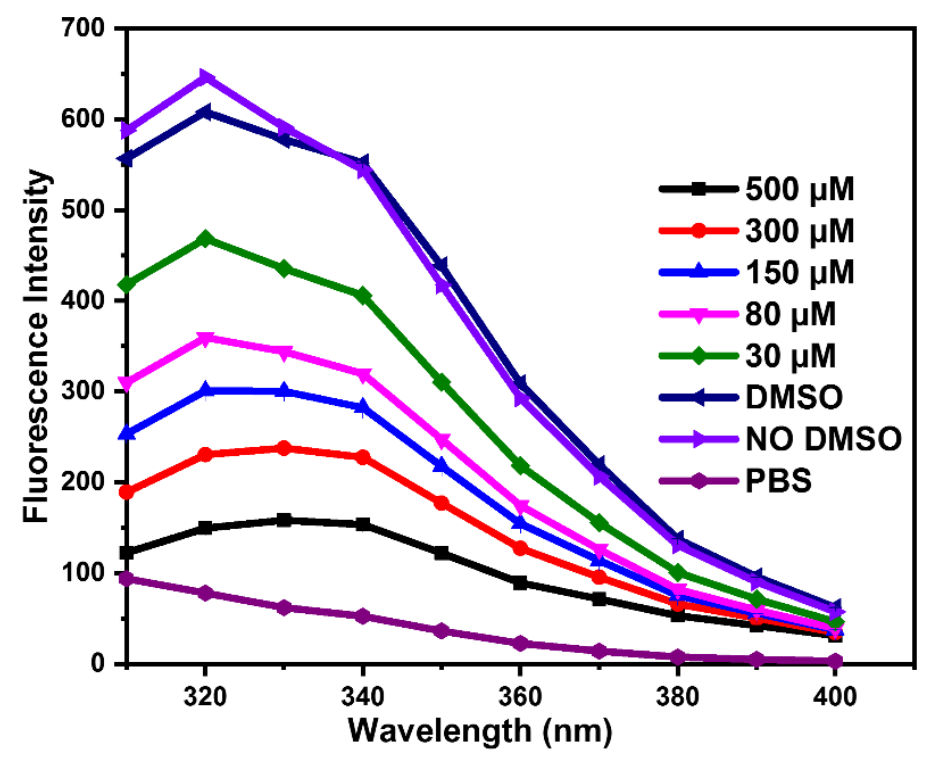

Figure S6: C82 effects on MTB CdnP intrinsic Fluorescence. Experiment conducted with $2 \mu \mathrm{M}$ MTB $\mathrm{CdnP}$ in 1x PBS with varying C82 concentrations. Enzyme-compound mix was incubated for 30 min at room temperature before reading fluorescence emission in $310 \mathrm{~nm}-400 \mathrm{~nm}$ range following an excitation at $290 \mathrm{~nm}$. 

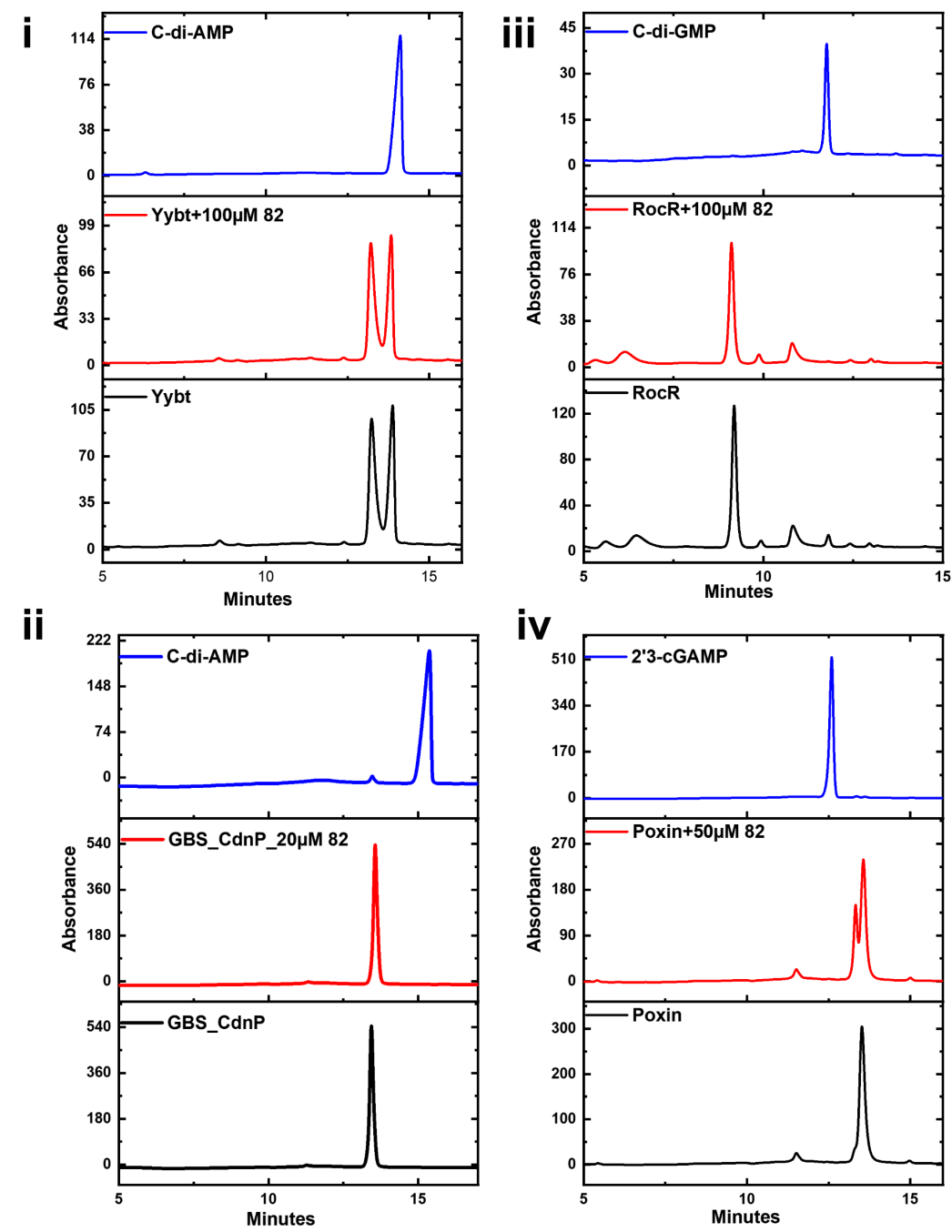

Figure S7a: C82 activity against other CDN PDEs. i) Yybt c-di-AMP cleavage in the presence and absence of C82. Reaction conducted with $0.5 \mu \mathrm{M}$ Yybt, $70 \mu \mathrm{M}$ c-di-AMP in 1x reaction buffer (100 mM Tris-HCl pH 9.5, $20 \mathrm{mM} \mathrm{KCl}, 0.5 \mathrm{mM} \mathrm{MnCl}$ ). Incubated for $1 \mathrm{~h}$ at $37{ }^{\circ} \mathrm{C}$. ii) GBS_CdnP c-di-AMP cleavage in the presence and absence of C82. Reaction conducted with $100 \mathrm{nM}$ GBS CdnP, $50 \mu \mathrm{M}$ c-diAMP in $1 \times$ reaction buffer ( $50 \mathrm{mM}$ Tris- $\mathrm{HCl} \mathrm{pH} \mathrm{8.0,5} \mathrm{mM} \mathrm{MnCl}_{2}$ ). Incubated for $1 \mathrm{~h}$ at $37^{\circ} \mathrm{C}$. iii) RocR cdi-GMP cleavage in the presence and absence of C82. Reaction conducted with $250 \mathrm{nM}$ RocR, $25 \mu \mathrm{M}$ cdi-GMP in $1 x$ reaction buffer $(100 \mathrm{mM}$ Tris- $\mathrm{HCl} \mathrm{pH} \mathrm{8.0,20} \mathrm{mM} \mathrm{KCl,} 25 \mathrm{mM} \mathrm{MgCl}$ ). Incubated for $1 \mathrm{~h}$ at $37^{\circ} \mathrm{C}$. iv) Poxin 2'3-cGAMP cleavage in the presence and absence of C82. Reaction conducted with 250 $\mathrm{nM}$ poxin, $20 \mu \mathrm{M}$ cGAMP in $1 \mathrm{x}$ reaction buffer (50 mM Hepes-KOH pH 7.5, $35 \mathrm{mM} \mathrm{KCl}, 1 \mathrm{mM}$ DTT). Incubated for $30 \mathrm{~min}$ at $37^{\circ} \mathrm{C}$ 
The C82 activity against the other CDN PDEs indicated that C82 was not an inhibitor of these enzymes (Figure S7a). To determine if C82 had even marginal inhibitory effect on the enzymes, the enzymatic reactions were slowed down and higher concentrations of C82 (up to $200 \mu \mathrm{M}$ ) used, Figure S7b.

\section{a)}

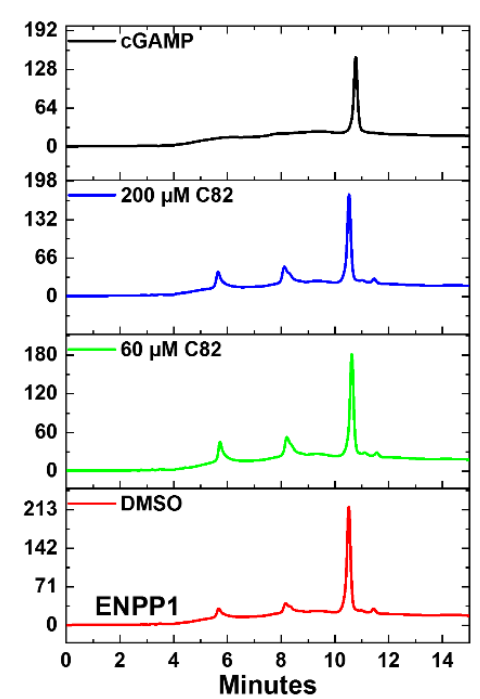

b)

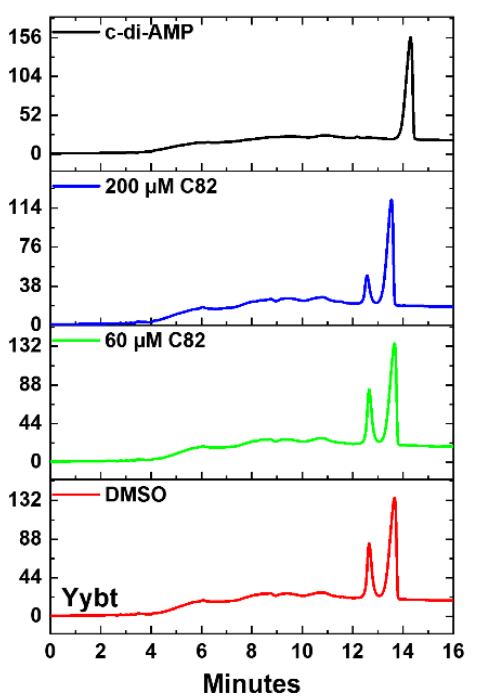

c)

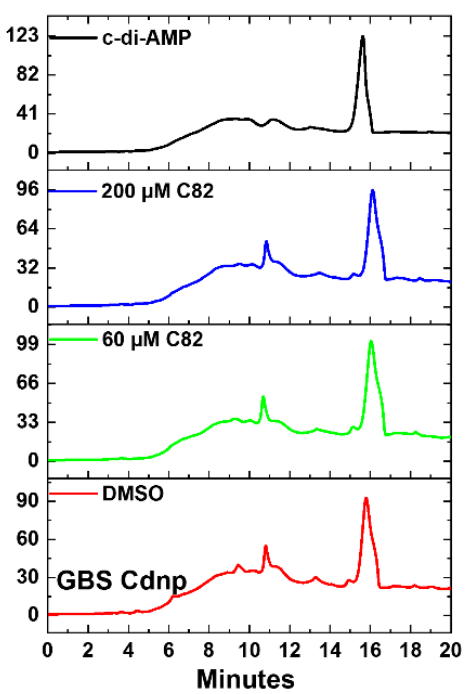

d)

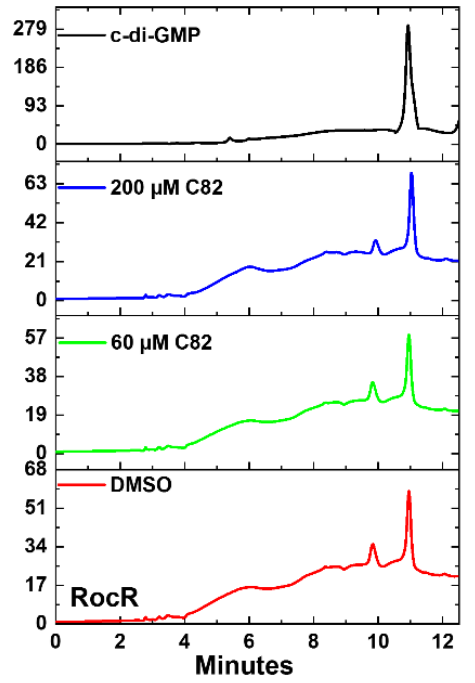

e)

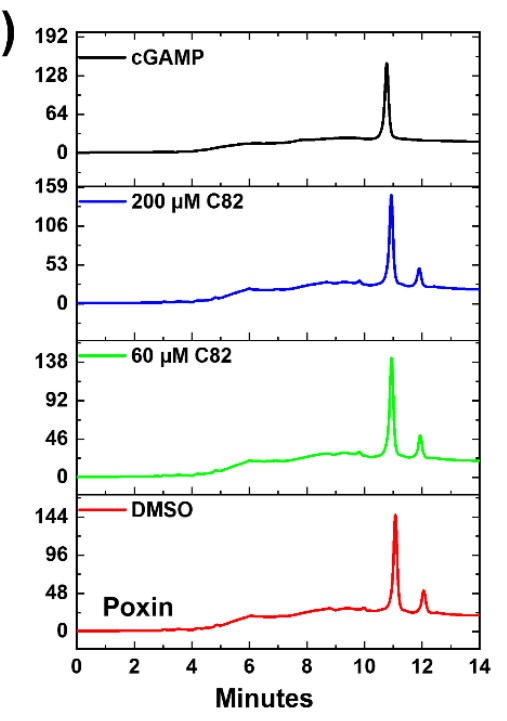

Figure S7b: C82 activity against other CDN PDEs. a) ENPP1 cGAMP cleavage in the presence and absence of C82. Reaction conducted with $4.58 \mathrm{nM}$ ENPP1, $20 \mu \mathrm{M}$ cGAMP in 1x reaction buffer (50 mM Tris, pH $9.5250 \mathrm{mM} \mathrm{NaCl}$ ). Incubated for $1 \mathrm{~h}$ at $37^{\circ} \mathrm{C}$. b) Yybt c-di-AMP cleavage in the presence and absence of C82. Reaction conducted with $1 \mu \mathrm{M}$ Yybt, $70 \mu \mathrm{M}$ c-di-AMP in $1 \mathrm{x}$ reaction buffer (100 mM Tris$\mathrm{HCl} \mathrm{pH} \mathrm{9.5,} 20 \mathrm{mM} \mathrm{KCl}, 0.5 \mathrm{mM} \mathrm{MnCl}$ ). Incubated for $1 \mathrm{~h}$ at $37^{\circ} \mathrm{C}$. c) GBS_CdnP c-di-AMP cleavage in the presence and absence of C82. Reaction conducted with $100 \mathrm{nM}$ GBS CdnP, $70 \mu \mathrm{M}$ c-di-AMP in 1x reaction buffer ( $50 \mathrm{mM}$ Tris- $\mathrm{HCl} \mathrm{pH} \mathrm{8.0,5} \mathrm{mM} \mathrm{MnCl}_{2}$ ). Incubated for $15 \mathrm{~min}$ at room temperature. d) RocR c-di-GMP cleavage in the presence and absence of C82. Reaction conducted with $10 \mathrm{nM} \mathrm{RocR,} 5$ $\mu \mathrm{M}$ c-di-GMP in $1 \mathrm{x}$ reaction buffer $(100 \mathrm{mM}$ Tris- $\mathrm{HCl} \mathrm{pH} 8.0,20 \mathrm{mM} \mathrm{KCl}, 25 \mathrm{mM} \mathrm{MgCl}$ ). Incubated for 1 $\mathrm{h}$ at $37^{\circ} \mathrm{C}$. e) Poxin 2'3-cGAMP cleavage in the presence and absence of C82. Reaction conducted with $5 \mathrm{nM}$ poxin, $20 \mu \mathrm{M}$ cGAMP in $1 \mathrm{x}$ reaction buffer (50 mM Hepes-KOH pH 7.5, $35 \mathrm{mM} \mathrm{KCl}, 1 \mathrm{mM}$ DTT). Incubated for $20 \mathrm{~min}$ at room temperature 
a)

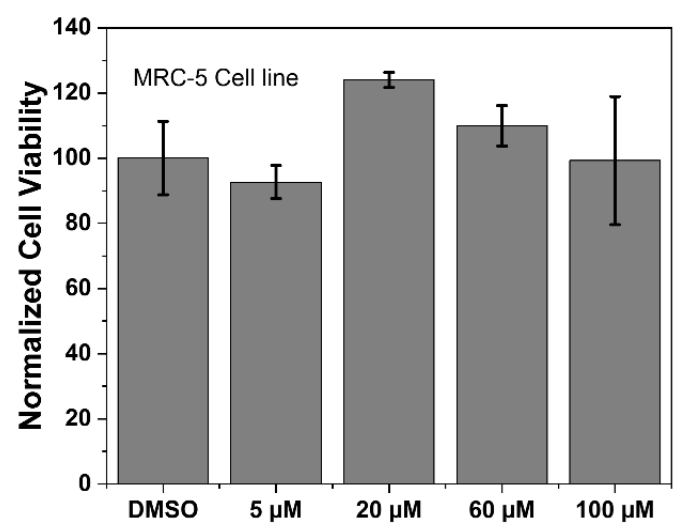

b)

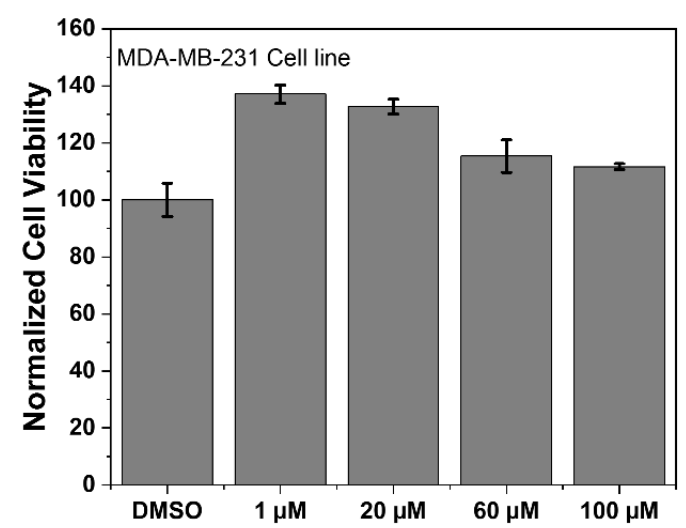

Figure S8: $\mathbf{C 8 2}$ is not cytotoxic against mammalian cell lines. a) MRC- 5 cell line incubated with C82 $(24 \mathrm{~h})$. b) MDA-MB-231 cell line incubated with C82 $(24 \mathrm{~h})$. Cell viability was quantified with CellTiterBlue ${ }^{\circ}$ Cell Viability Assay kit.

\section{Reference:}

Karanja, C. W.; Yeboah, K. S.; Ong, W. W. S.; Sintim, H. O., A STING-based fluorescent polarization assay for monitoring activities of cyclic dinucleotide metabolizing enzymes. RSC Chem. Biol. 2021, DOI: $10.1039 / d 0 c b 00187 b$ 